\title{
Developing a Control System in Order to Determine the Role of Economy
}

\author{
Krylov A.A ${ }^{1 *}$, Pobyvayev S.A ${ }^{2}$, Selivanov A.I ${ }^{3}$, Silvestrov S.N $^{4}$, Starovoitov V.G ${ }^{5}$, Troshin D.V ${ }^{6}$ \\ ${ }^{1}$ Doctor of Economic Sciences (Advanced Doctor), Professor, Chief Research Officer, Institute of Internal Affairs of Russia, Moscow, \\ Russia. \\ ${ }^{2}$ Candidate of Economic Sciences (Ph.D.), Senior Research Officer, Institute of Economic Policy and Economic Security, Financial \\ University under the Government of the Russian Federation, Moscow, Russia. \\ ${ }^{3}$ Doctor of Philosophical Sciences (Advanced Doctor), Professor, Chief Research Officer, Institute of Economic Policy and Economic \\ Security, Financial University under the Government of the Russian Federation, Moscow, Russia. \\ ${ }^{4}$ Doctor of Economic Sciences (Advanced Doctor), Professor, Director of the Institute of Economic Policy and Economic Security, Fi- \\ nancial University under the Government of the Russian Federation, Moscow, Russia. \\ ${ }^{5}$ Doctor of Economic Sciences (Advanced Doctor), Director of the Center for Economic Security and Monitoring, Institute of Economic \\ Policy and Economic Security, Financial University under the Government of the Russian Federation, Moscow, Russia. \\ ${ }^{6}$ Candidate of Engineering Sciences (Ph.D.), Senior Research Officer, Institute of Economic Policy and Economic Security, Financial \\ University under the Government of the Russian Federation, Moscow, Russia \\ *Corresponding author E-mail:
}

\begin{abstract}
The task of the authors was to develop a certain control system to identify the role of country economic security in the Eurasian integration. To this end, the approaches to economic security in Europe, Russia and Asian countries are analyzed. The differences in the methods of controlling the national economic security and in the key approaches to its provision are primarily due to the historically established internal economic and geo-economic conditions. There is a fairly wide range of paradigms of controlling system implemented in national economic security, primarily the differences between the European approaches and the approach of Russia. Given information based on mentioned control systems revealed that principles and mechanisms of organization of national economic security systems in Asian countries is practically absent in Russian science. It was also necessary to analyze the typology of control monitoring system in order to clarify the prospects of integration of national economic security systems. The authors substantiate the position that ensuring national economic security is an important imperative of integration and development in the Eurasian space, competitiveness and economic sovereignty of countries. The article systematically organizes the facts about the types of organization of national economic security, explains the need for the countries of Eurasia active control system of economic security as a response to the challenges of our time. The authors express a certain control syste, of Eurasian integration in the field of national security, involving both sovereignty and harmonization of national systems aimed at protecting economic interests.
\end{abstract}

Keywords: control systems for national economy; controlling the economic security; Eurasian integration; national security system; collective system of economic security.

\section{Introduction}

The Nano-structure materials are classified as hard materials with Nano-scale microstructures which generally lie The system of ensuring economic security on a national scale is an indispensable element of the system of public administration and is organically integrated into the system of controlling state. The nature, mechanisms and institutions of such a system vary depending on many factors. Accordingly, the control system of each state in the implementation of global integration projects can be implemented in various forms. Various approaches to the formation of collective mechanisms of economic security in the created integration entities, in the implementation of specific joint projects may also be proposed. This should be taken into account in the formation of economic security systems in Eurasia.

Subject area of the article is controlling the economic security of Russia and other countries in the Eurasian integration processes.
Purposes. To analyze existed control systems to ensuring economic security in various countries of Europe and Asia, to assess the state of scientific support of economic security in relation to the Eurasian integration in Russian science.

Results.

The active participation of the Russian Federation in ensuring international economic security in Eurasia is an objectively inevitable component of its integration activity and therefore the problem of ensuring Russia's economic security, which will be required and will be increasingly required by the Russian leadership, and therefore this range of problems should be considered as a special, serious and long - term scientific task. At the same time, Eurasian integration is a complex and multifaceted process. An important element of management in the integration processes and entities is to ensure national economic security and obtain additional effects in this area from the integration procedures. Different countries provide different economic security in different aspects, including the protection of their own economic entities. 
Russia has its own experience in ensuring economic security, its own scientific approaches to the study of this problem. However, they are not sufficient to solve the complex problem that Russia faces and potentially will face in the course of the Eurasian integration processes. Moreover, studies in this aspect, in relation to the study of the economic security of Asian countries, in Russia are extremely insufficient, and in many aspects only unfold. This requires switching the attention of the scientific community to this aspect of the problem of ensuring Russia's economic security and intensifying research in this direction. In addition, there is every reason to take a broader approach to the interpretation of the concept of "economic security", including in the scope of this concept as competitiveness, strategic management, inter-country relations, and technological, cultural and other aspects that in the format of Eurasian integration become organic elements of the complex of economic security. Only such an approach can ensure the most complete response to the risks and threats to Russia's economic security in the current period and in the distant future.

The current state of scientific support in the Eurasian integration processes in Russia is unsatisfactory, which determines the urgency of the problem. In this regard, the discussion of approaches to the problem statement, undertaken in this article, is considered as an important step to the beginning of scientific discussion.

\section{Methodology and Methods}

In the following presentation we are based on the analysis of current scientific literature, state official documents and national statistical reporting. The main methods of research are historical review, comparison, analysis of the fundamental principles of the organization of national economic security systems, a systematic approach.

\section{Results and Discussion}

\subsection{History of problem research in the world and in Russia}

For several decades, the Russian and international scientific community has been comprehensively studying the phenomenon of economic security - both in the complex and in various respects, spheres and sectors, including the shadow and criminal economy, the nature of corruption, in the sphere of customs regulation, in the framework of international integration of law enforcement aspects and combating economic crime, etc.

It is clear that due to the differences in the country's economic systems, the perspectives and intensity of scientific research on economic security problems differ. Let us briefly dwell on this, having previously focused on the following: many aspects of economic security, mechanisms, institutions, forces, means, activities, research results are naturally classified in each country. This is due to the fact that developments in the field of economic security are directly related to the success and competitiveness of the national economy, its prospects, the socio-economic situation in the country, and therefore - with the prospects of the system of power that exists in this period. So, in world literature after 80-ies modern developments in the field of strategic management in the individual countries, research protoplasmic factors and competitive advantages, economic security, analytical studies, etc. have virtually disappeared in open access.

Today, in Western countries, much less attention is paid to the problems of economic security, especially on a national scale, than in Russia. Here, more attention is paid to the effectiveness of economic mechanisms and management (see, for example: Ranci, C., Parma, A., Bernardi, L., Beckfield, J.). The very concept of "economic security" in these countries either expands to national security or narrows down exclusively to the assessment of various business risks. As a rule, attention is paid to cybersecurity, economic crime, and risk management in the implementation of projects of various scales from the issues of the complex of economic theory of security. Special serious studies on economic security in the countries of Eurasia are also practically unknown in Russian science. Even the very concept of "security" in the context of Eurasia is only making its way as in the practice of integration processes (see, for example: Stupakov N.V.) the same is true in science, which so far has only raised this issue at a number of pioneering conferences in this regard (Analysis of development, security and cooperation: Greater Eurasia - 2030; Greater Eurasia: Development, security, cooperation. Yearbook.) Although, for example, a high level of protection of the Chinese economy during the global financial and economic crisis of 2007-2009 was demonstrated. (Yu Yongding), which, of course, is not an accident, but the result of the directed work, well-established precisely on the scale of the state, which has developed and proposed to the national economy and economic entities a set of very effective anticrisis mechanisms with the active participation of the state itself (Gordienko D.V., Prazdnov G.S.).

In Russia, problems in ensuring the security of the national economy in the post-Soviet period of an open liberal market economy began to be revealed and identified by Russian science in the 1980 s, at the very beginning of the era of "openness" of the domestic economy and the beginning of a new stage of transformation of the world economy. This is due to the fact that even then experts have become aware of many trends, including the negative: the growth of the shadow and criminal economy, the formation of systems of laundering of criminal proceeds, systemic corruption, rough competitive squeezing from the world markets of some countries by others, the formation and use of offshore jurisdictions for illegal withdrawal of capital, etc.

One of the most important methodological approaches was developed at the Institute of Economics of RAS. It was aimed at identifying the challenges and threats to economic security, determining the threshold values of indicators and subsequently began to communicate, first of all, with a team of researchers led by V.K. Senchagov (a summary of experience, see: Innovative transformation as an imperative of sustainable development and economic security of Russia; Economic security of Russia). The development of this approach was initially aimed at the possibility of using the results in the direct practice of public administration. The methodological basis laid down in these studies proved to be very stable, it was reproduced and used in a variety of studies.

However, the level of interest and the range of discussed problems of economic security as threats to national security in the economic sphere in Russia is developing in a wave-like manner, passing through the phases of reducing attention throughout the postreform period. Ignoring economic security problems usually begins in favorable periods for the economy (for example, from 2003 to 2012), and the increase - in unfavorable (after 2014 to 2018). Russian management culture, apparently, has not outlived the properties noted at the level of folklore, such as "until the thunder breaks, the man will not cross himself". In strict accordance with this element of popular wisdom, events have taken place around a set of economic security problems. For example, before the introduction of sanctions and the fall in oil prices, the emergence on this basis of acute problems in the economy, the growth of threats to the economic sovereignty of the country, the problem of economic security remained on the periphery of the practice of public administration. It was during these years that the problems of ensuring economic security and combating economic crime in the course of reforms of the Ministry of Internal Affairs of Russia disappeared from the Federal law "On police" (it is still not in the main activities of the Ministry of Internal Affairs), even the Academy of Economic Security of the Russian Interior Ministry was liquidated. 


\subsection{Approaches to economic security in different coun- tries of the world}

The nature, mechanisms and institutions of the national system of economic security vary depending on many factors: national traditions; the scale of the country and the characteristics of its economy in the global dimension; socio-economic model; the nature and activity of economic entities in its territory; the dominant sectors of the national economy; the nature of competition; the nature of the historical period; political and geopolitical interests of different countries in certain segments of the economy; the current relations between state institutions and economic entities, etc. Important to discuss the economic security of the countries of Eurasia is the understanding of Russian science, the main forms of provision of protection of national economy from external and internal threats, which can be: economic patronage, economic cooperation and economic antagonism (Orekhov V.I., Orekhova T.R., Karagodina O.V.; Savitskaya E.A.; Economic security of the Russian Federation. In 2 vol.).

Thus, Western European culture (currently led by the United States, the EU) professes the principles of active offensive, initiative, attack, capture, often moving to aggressive actions against other countries and their economic entities in different types from "hot", "cold", economic, "hybrid" wars and "color" revolutions - economic sanctions, blockades, violations of longestablished international agreements (WTO, climate agreements, non-proliferation of toxic substances, nuclear weapons, etc.), which are becoming more aggressive if these countries start to lose in economic competition (Glazyev S.Yu. (2016)). This type of economic aggression is automatically an instrument of active protection. In addition, to ensure directly the security of their territories, businesses, their domestic and controlled foreign markets, these countries also use active actions - control of global finance (O'Brien, R.) and their use to influence other countries of the world (today - through the IMF, the World Bank), the creation of economic unions, the introduction of various customs and other restrictions, the creation of free trade areas, customs unions with their own "rules", breaking all sorts (including themselves created) rules and international norms that have become unnecessary, the direct destruction and/or subjugation of rivals, as it did with the enterprises of the USSR after the restructuring (see especially: Doronin A. I.) or economic action against national and state economies (Perkins George). Undoubtedly, in the current situation, the United States and its partners, acting in the same paradigm, will make various attempts to oppose the Eurasian integration processes, thereby creating new threats to national and international economic security in Eurasia. In particular, they will come from sanctions regimes against Russia, China, Iran, other Eurasian countries, and Afghanistan. This method of protection can be defined as active force pressure.

With the dominant activity of Western civilization in the modern period, this nature of its aggressiveness creates a situation for all other countries of the need to combine in their actions a) independent activity, ensuring national competitiveness and b) aimed at ensuring economic security, including the provision of national economic sovereignty.

To ensure the economic security of Russia and most of the Eurasian countries, the nature of the activity of the economic leaders of the Asian region - China, India, Japan, South Korea, Malaysia and Vietnam - is also important. These economies grow as the economy of mass production of cheap goods were formed in the effective economic system, outstripping the rate of growth of the Western economy, caught up and overtook many of them. They are the main reference point for the organization and management of economies aimed at the tradition, the dominance of public interests (in some countries - on the basis of socialism), the active introduction of innovation, the capture of mass markets, the protection of their own national economic systems (see in particular: Hermann-Pillath, C.; Masayuki Tanimoto; Yul Kwon, O). And, as the adviser to the President of the Russian Federation, academician S.Yu. Glazyev notes - in the East, in the culture of which the general dominates over the private, organically distant goals are formed and strategies are built (Glazyev S.Yu.(2018)), which creates huge advantages in the era of management of the future, the era of national-state strategic management.

At the same time, the problem of ensuring Russia's economic security in Eurasian relations, in the course of integration processes, within the existing integration entities, such as the CIS, SCO, EAEU, in relations with other economic unions, especially SouthEast Asia, is practically not studied in the Russian scientific literature, as evidenced by the analysis of the history of the problem. In addition, the problems of ensuring individual and collective economic security of the Eurasian countries within the framework of economic unions created with the participation of Russia, as well as the possible experience of individual and collective solutions in this area within the framework of other economic unions of the Far East and South-East Asia, are not studied.

\subsection{Economic security in Eurasia in the course of inte- gration}

Building a collective system of economic security and/or integration in this direction is a natural component of any integration process, including in the process of Eurasian integration in all its dimensions and organizational forms. Based on the fact that ensuring the economic security of countries in the Eurasian space, including associations of countries, including the CIS, EAEU, SCO, is, on the one hand, an organic component of the management system of each individual country, and on the other - the search for ways of communication and integration in order to obtain a single synergetic effect that enhances the economic security of each country as a result of the collective efforts of all countries.

Let us briefly analyze the range of these trends and problems. Only the possibility of such an effect is (may be) attractive to countries when joining economic unions and building an integrated system or integrated components of the economic security system. However, economic security is definitely an additional "assembly point" for coordination and cooperation of national economic systems in Eurasia.

It is clear that this should follow the path of harmonizing the interests of various countries in the sphere of economic security. It is also clear that this integration will have a multi-level character, which is determined by various combinations of internal and external threats in the complex of threats to the national economies of different countries. Such detail is also important: the "small Eurasia", which includes the countries of the former USSR, will be one strategy that should be combined and integrated into the strategy in the "great Eurasia", which includes China, South and North Korea, India, Vietnam, Malaysia, Iran, relations with which are also far from simple and even more sincerely allied, whose economies also carry a lot of threats to the countries of "small Eurasia" (Vinokurov, E., Libman, A.).

Unity and ways of integration in the sphere of economic security should be sought both in the sources of threats and in the mechanisms and institutions to counter them.

Domestic threats to the national economic security of the CIS countries are similar - criminalization of the economy, export of capital to offshore jurisdictions, large-scale unregistered economic relations, as well as dependence on world markets for raw materials and imports, both high-tech products and consumer goods. In addition, internal threats to economic security include ineffective strategic management, a deformed financial system, the weakness of the national-oriented vector in the economy, the oppression of innovative development (science, education, values), cultural, educational and other spiritual deformations, irrational sectoral and territorial development of production, socially dangerous differentiation of the level and quality of life of the population, deg- 
radation of housing and communal services, weak control of customs space and low level.

It is clear that the uniformity of threats does not mean their identity, because the subjects of these threats are different in each country and integration can be found only in the general scientific and methodological support, the formation of international legal institutions and economic conditions aimed at minimizing the negative effects of various threats, in some cases - a single organizational structures and infrastructures.

And, often attempts to find something in common - for example, innovative solutions from others in order to try to apply them at home, as well as to identify ways to introduce their own scientific developments in the field of economic security, strategic management and development in other countries.

External threats to the countries of Eurasia come from many countries, including the Eurasian "partners" (De Waal, T.). Here, unity must be sought by matching the interests of specific countries and by common sources of threats. Such sources of common threats are many - the US, EU countries, criminal entities, offshore jurisdictions, etc. There is current specificity - Russia and some other countries subject to sanctions by the USA and its satellites. Sanctions also apply to those organizations and countries that engage in business and political interaction in the sanctions zones.

\subsection{Geo-economic, technological and cultural aspects of Russia's economic security in the process of Eurasian integration}

It is important to use and build Russia's scientific and theoretical experience in ensuring economic security on the basis of the tradition of the complexity of any problem that has not been lost yet. In particular, in the sphere of economic security, it is necessary to expand the subject area by more active involvement of political, economic, legal, social, moral, general cultural aspects. Based on this vision, today the important aspects of economic security of states are geo-economic (cross-country and regional), technological, cultural and other threats and systemic risks to the national economies of specific countries in the process of Eurasian integration. Without these components, the discussion and solution of the problem of ensuring the security of national economies become incomplete and do not cover the whole range of threats and risks. Some of these aspects stem from the nature of competition in certain regions, in the markets of certain goods or services, others from the structure of national economies of different countries and trends in their development in different sectors, and others - from cultural and linguistic communication between the peoples of different countries associated with a variety of aspects of economic integration. It is important to understand that these aspects can not be ignored in the analysis of the overall complex of economic security of the country in the long term, reducing the study of the problem only to the above traditional for the Russian economic and legal sciences problems of economic security. Here are some important examples.

The first example. The phenomenon of the growing influence of China's economy in the world, despite the whole positive group of assessments, is also contradictory for Russia (Russia-China: Future changes in Siberia). Thus, China with huge volumes of production in this country consistently realizes its economic interests not only in the world, but also in the post-Soviet republics, in Central Asia, in Russia itself, acting as a direct competitor to Russian producers. As a result of China's unseen competition in Russia, entire sectors of the economy, starting with light industry, have been destroyed. And other Russian goods are being pushed out of markets, such as Central Asia, often resembling a local trade war (China's Invasion of Central Asia; China's ousting Russia from the oil and gas equipment markets of Central Asia). Such moment is also important. China always acts and will act only in its own interests. Russia needs to take this into account especially, because it is used to enroll all in the "partners", including competitors and recent enemies, and "partners" enroll in "friends", which they often are not and Russia as their "friends" was not considered. This became clear in relation to the West; this should be borne in mind in relation to China. For example, China, without taking into account the interests of Russia, is implementing the "silk wind" railway project with Europe, which was undertaken bypassing the Russian territory. In general, there is a very serious threat to the implementation of Eurasian integration in Central Asia according to the Chinese scenario, which ignores the interests of Russia. Therefore, such an ill-wisher of Russia as Z. Bzhezinsky had serious grounds for the following statement: "Therefore, the prospects of Russia at the head of the Eurasian Union are a fiction. And this Union will fall apart for economic, social and personal reasons. As a result, it will only lead to Russia's growing unwillingness to meet the growing influence of China in Central Asia" (Russia vs China). Similarly, it is necessary to consider the intersection of Russia's interests with other countries in the Eurasian space in the context of competition and economic security.

The second example. Currently, the Russian economy has a dominant raw material orientation. At the same time, the transition to the sixth technological mode is the main trend of modernity, the implementation of objective laws of human development. There is no doubt that in this regard, this vector should be one of the key in the analysis and practical provision of economic security on a national scale. However, this is not happening yet. In the Russian economic and legal science there is no answer to many questions related to the specifics of economic security in the new segments of the economy of the sixth technological structure, with new (existing and possible) types of economic crime, with the evolution of the shadow and criminal economies, etc. (for more details, see: Selivanov A.I., Starovoytov V.G., Troshin D.V.) So, Eurasian integration on the basis of raw materials as an externally attractive process for Russia weakens the level of its economic security and competitiveness in the transition to the sixth technological mode. Already today, this leads to the stagnation of the Russian economy, brain drain, deformations in the organization of science and education systems as key "producers" in the high-tech economy. Moreover, as always in the history of mankind, new achievements are used not only for good, but also for evil. For example, on the basis of new technologies, shadow and criminal segments of the economy will become more "smart", intellectually saturated and organizationally new. In this regard, Russia, lagging behind in the pace of technological development from a number of Eurasian countries, in the context of Eurasian integration, will face a) more technologically advanced producers as competitors, b) new threats and risks associated with the new economy and c) new types of economic crime, etc. However, in scientific research and practical development of these threats and risks in the context of economic security, Russia is almost at zero point now.

The third example is the problem of economic security in the context of cultural tradition, international communication and cultural rapprochement. This problem seems less acute, but the nature of integration processes in the Eurasian space largely depends on its solution. In the West, such studies have been conducted for a long time due to their importance (see, for example: Goheen J., Srinivas M. N., Karve D. G., Singer M.), in Russia, there are also country studies of the impact of cultural traditions on the economy, including the Asian countries. However, there is no research on the impact of various aspects of culture on the specifics of economic security. This is becoming very important for modern Russia.

So, first of all, it should be about Russian as a language of international communication in Central Asia in at least two aspects. First, there are large volumes of labour migration to Russia from Central Asia, currently it estimated at 4 million people. Naturally, the Russian language will undoubtedly be in demand in the future. However, this is clearly not enough. There is a second, deeper aspect - for the implementation of Russian projects in Eurasia, including taking into account the economic security, it is advisable to closer cultural rapprochement, the restoration of the common 
cultural space, which is now largely destroyed and continues to collapse, including such "small" steps as the replacement of the Cyrillic alphabet to the Latin alphabet in Kazakhstan. There is a real threat that the cultural divergence between the peoples of Central Asia and Russia will increase.

Naturally, this will strengthen the non-Russian vectors of economic orientation of the economies of these countries, creating additional threats and risks. In this regard, cultural communication should be considered as the most important imperative of economic security and we can fully agree with Yu.I. Ilyina, who formulated the task of cultural communication of the peoples of Eurasia as follows: "In practice, this means that ideally, the Russian should know and understand in the original language, for example, poetry of Nizami Ganjavi, Rudaki, Khayam or philosophical works of Ibn Sina, and the Uzbek or Tajik, freely read the works of Pushkin, Lermontov, Tolstoy, Dostoevsky" (Ilyina Yu. I.).

This proves that the problems of economic security in the process of Eurasian integration should be considered much wider, involving in the circle of discussion, in particular, these aspects.

\subsection{Principles, tasks, prospects of integration processes in the sphere of economic security of Russia and Eurasia}

At the international conference "Our house - Eurasia" on September 27, 2018, S.Yu. Glazyev outlined the principles of Eurasian integration as an alternative to the "Washington consensus", which should become the basis for the "rediscovery" of the principles of international economic relations and the formation of international cooperation institutions for the entire world community. These are the following principles: voluntariness, mutual benefit, equality and transparency, mutual respect for national sovereignty, harmonization of interests and responsibility for achieving common goals. These principles have been aggressively violated by Western European countries for a long time.

The principle of complementarity and cooperation as a promising alternative to competition, as well as the principle of domination of public (collective) interests and interests of the national economy over private interests, including these principles as the basis for collective security of countries in the Eurasian expanses, should be added to these principles. It is also important, taking into account the experience of all Eurasian countries, to understand and accept as a basic dialectics of the principles of national economic sovereignty and ensuring the interstate level of security, regional Eurasian security and countering the aggressiveness of the West's actions (both current and provocative). An important component of economic security should also be a contractual legal regime to ensure it as a way of taking into account a combination of individual and common elements of economic security. It is also necessary to understand the organic relationship between security and development, when security is a condition for successful development, and continuous development, in turn, is a key component of effective national economic security.

The basic tool for ensuring effective economic security and competitiveness for intensive development is high-quality public administration, first of all - goal-setting and modern system of strategic management, based on the latest intellectual scientific support both in Russia and in the integration entities. It is here the main platform for joint research and project development, project organization and thus the institutionalization of systems of integration of strategic public administration, including in the field of economic security.

Naturally, it is necessary to take into account that the unification of elements in the system, states in the interstate formation, increasing their joint potential and security, inevitably leads to a partial loss of the degree of freedom and sovereignty. Otherwise, the system is unstable, and the coalition or union is a fiction. Harmonization of sovereign interests with the interests of the Alliance is an extremely difficult task today. Its solution in the applied aspect involves the formation and strengthening of traditions, the development of rules, regulations for the coordination of the sovereign position in international affairs with the allied debt. This decision should be based on a systematic analysis, development of philosophical, cultural, historical, political, legal approaches and justifications. However, the root of the approach to the solution is the awareness of the value of Eurasian integration, the expansion of the subject of its activities and the strengthening of the potential of economic security.

In this regard, the main directions of the search for integration in the field of economic security should be:

- coordination of strategic management and remote goal-setting; - unified approach to offshoring and creation of joint free development zones;

- use of mutually beneficial financial instruments;

- deep integration of law enforcement;

- consistent progress towards the creation of a common customs space;

- unification of elements of law and formation (ensuring) of an effective system of international law in the territory of Eurasia;

- accelerating the pace of integration in all areas of social and economic development (the dynamics of the world is growing); - scientific and information support of economic security.

Mechanisms of integration in the field of economic security: negotiations, joint projects and activities, the formation of common infrastructures (finance, information, libraries and databases), common methods and standards, the interaction of government and business structures in ensuring economic security.

We especially note that it is necessary to pay special attention and take special steps to stop a number of threats to the countries of the Eurasian space, integrating in the EAEU format.

\section{Conclusions}

Integration social and economic processes in Eurasia are objectively inevitable process. However, the economic components of this integration carry advantages and new prospects, as well as new threats and risks to Russia's economic security. At the same time, the Russian Federation has very little experience of comprehensive scientific research in ensuring integration processes in Eurasia, no knowledge of the state of economic security systems in these countries, no understanding of the possible negative effects for Russia under certain integration scenarios, no assessment of the sources of possible new threats in the socio-economic sphere. Understanding the presence of political will and the activity of the public administration system in the direction of Eurasian integration, research in this area should be considered as a special priority and long-term scientific task.

The task of scientific research in the field of economic security in integration processes has every reason to rely on existing scientific experience, but it must inevitably be solved more comprehensively, widely than it was solved and put in Russia in relation to "internal use". The range of problems of economic security should go far beyond the problems of the shadow economy, corruption, economic crime and related segments in the field of cross-country competition, integration effects in ensuring Eurasian economic security, analysis of the impact of the quality of public strategic management on the state of economic security, study of the specifics of economic security in the sixth technological stage, prospects of intercultural communication in their impact on the economy of Russia and Eurasian countries, etc.

It is clear that the Eurasian integration will be successful only if it is able to give additional effects both to ensure economic security and to intensify the development of national economies. This effect will create a consolidated center of power, which will provide a superposition to the current Anglo-Saxon center, attracting national resources around the world, including Eurasia, in the framework of global processes of economic, scientific, technical and even cultural development. 
However, the lack of a clear development project of the initiator and the modern center of Eurasian integration in the post-Soviet space in the face of Russia makes such integration politically unattractive and risky. Partner countries tend to take a wait-and-see attitude, and not to enter into projects that would imply irreversible changes and the inability to return to the "status quo". Moreover, they will seek to form their own Eurasian projects bypassing Russia, which can create additional threats and risks for it.

\section{References}

[1] Analytics of development, security and cooperation: Greater Eurasia - 2030. Proceedings of the IV International scientific-practical conference. M: Publishing House Kogito-center. 253 p.

[2] Greater Eurasia: Development, security, cooperation. Yearbook. M.: INION RAS, 2018. Vol. 1, part 1. 612 p.

[3] China's invasion of Central Asia. Electronic resource. URL: https://pikabu.ru/story/vtorzhenie_kitaya_v_srednyuyu_aziyu_4231 232

[4] Glazyev S.Yu. The Last world war. The US starts and loses. M. Book world, 2016. 512 p.

[5] Glazyev S.Yu. Leap into the future. Russia is in a new technological and world economic order. M.: Book world, 2018. 768 p.

[6] Gordienko D.V., Prazdnov G.S. Ensuring economic security of the People's Republic of China in the implementation of the strategy of the economic belt of the silk road// National interests: priorities and security. 2018. Vol. 14, issue. 2. P. 377-392.

[7] Doronin A.I. Business intelligence. 5-e ed. M.: “Os-89”, 2013. 704 p.

[8] Ilyina Yu. I. "Eurasian Islam": problems and ways of their solution: Theses of the speech at the forum "National self-knowledge of the peoples of the Eurasian integration countries". Moscow, 29 June 2017 (Cit. by: Samsonkin Yu. Common past - common future// Eurasianism of the Russian Federation. Electronic resource. Электронный pecypc. URL: https://xn--80adbjmgh5bmol.xn-p1ai/novosti-resursa/item/293-obshchee-proshloe-fundamentobshchego-budushchego.html)

[9] Innovative transformation as an imperative for sustainable development and economic security of Russia/ Under the editorship of V.K. Senchagov. - M.: “Ankil”, 2013. - 688 p.

[10] China displaces Russia from the oil and gas equipment markets of Central Asia. Electronic resource. URL: http://www.energyland.info/analitic-show-79908

[11] Orekhov V.I., Orekhova T.R., Karagodina O.V. Economic security of modern Russia in crisis: monograph. M.: INFRA-M, 2014. 105 p.

[12] Perkins George. Confessions of an economic killer. 2-e ed. M.: Pretext, 2014. $350 \mathrm{p}$.

[13] Russia vs China. Is fight for Central Asia ahead?// Military review. Electronic resource. URL: http://newsinmir.com/politics/12109 rossiya-vs-kitay-shvatka-za-srednyuyu-aziyu-vperedi.html

[14] Savitskaya E.A. Economic security of the state in the context of globalization: monograph. Tyumen: Publishing house of Tyumen State Agricultural Academy, 2007. $117 \mathrm{p}$

[15] Selivanov A. I., Starovoitov V.G., Troshin D.V. Economic security in the conditions of transition to the sixth technological mode: problem statement// Security business. 2017. No. 6. P. 10-16.

[16] Stupakov N.V. The role of integration cooperation of Eurasian states in ensuring interaction and compromise of economic, political, defense and security interests: results of the SCO summit 2017// International cooperation of Eurasian states: politics, economics, law. Vol. 2, №11, 2017. P. 14-25.

[17] Economic security of Russia. General course: the textbook/ Under the editorship of V.K. Senchagov. 3-e ed. - M.: BINOM. Laboratory of knowledge, 2009. $-815 \mathrm{p}$.

[18] Economic security of the Russian Federation. In 2 volumes / Under the general editorship of S.V. Stepashin. Moscow: Lan', 2001. 1248 p.

[19] De Waal, T. (2011) Conflict in Eurasia. February 03, Eurasia Foundation. Electronic resource. URL: https://carnegieeurope.eu/2011/02/03/conflict-in-eurasia-pub-42776,

[20] Goheen J., Srinivas M. N., Karve D. G., Singer M. (1958) India's Cultural Values and Economic Development: A Discussion, Economic Development and Cultural Change, Vol. 7, No. 1, Oct., pp. $1-12$.
[21] Herrmann-Pillath, C. (2005) Culture, Economic Style and the Nature of the Chinese Economic System, Herdecke University, Germany, Hong Kong, January 15.

[22] Masayuki Tanimoto. (2006) The Role of Tradition in Japan's Industrialization: Another Path to Industrialization, Published to Oxford Scholarship Online: September, 2006.

[23] O'Brien, R. (1995) Who Rules the World's Financial Markets? Harvard Business Review, March-April.

[24] Ranci, C., Parma, A., Bernardi, L., Beckfield, J. (2017) The rise of economic insecurity in the EU: concepts and measures.Lives Working Paper, vol. 62, P. 1-29.

[25] Russia-China: Future changes in Siberia. (2016) LEAP (Laboratoire européen d'Anticipation Politique). 26 July 2016. Electronic resource. URL: http://www.leap2020.net/russie-chine-mutationsdavenir-en-siberie/?lang=en, Обращение 05.09.2018.

[26] Vinokurov, E., Libman, A. Eurasian integration and its institutions: possible contributions to security in Eurasia. (2017) Eurasian Development Bank, Ludwig Maximilians University of Munich.

[27] Yu Yongding. China's Policy Responses to the Global Financial Crisis. (2009). Australian Government, Productivity Commission, November, Richard Snape Lecture 25, Melbourne.

[28] Yul Kwon, O. Does culture matter for economic development in Korea? (2011) The Journal of East Asian Affairs, Vol. 25, No. 2, p. 163-182.

[29] Abuzjarova M.I. Tendencies, law of development and economic content of innovative entrepreneurship // Modern Economy Success. 2018. No. 1. Pp. 43-50.

[30] Borovikova T.V. Methodological bases of formation of the intellectual potential of territories in the conditions of innovative economy // Modern Economy Success. 2017. No. 6. Pp. 46-49.

[31] Gadzaov A.F., Dzerzhinskaya M.R. Mathematical methods of analysis of the periodic components of economic processes // Modern Economy Success. 2018. No. 1. Pp. 14-18.

[32] Makeeva A.A., Chubarova E.A., Mishanova V.G. Risk management as an element of enterprise management // Successes of Modern Science and Education. 2018. No. 2. Pp. 10-14.

[33] Minakova I.V. Social and economic condition of Russia and possibility of its transition to innovative hi-tech model // Modern Economy Success. 2017. No. 6. Pp. 24-27.

[34] Novikov S.V. Government stimulation and regulation of russian innovation producers export expansion // Modern Economy Success. 2017. No. 3. Pp. 24-27. 